\title{
Pengaruh Model Pembelajaran Inkuiri Terbimbing Berbasis Peer Instruction Terhadap Hasil Belajar Fisika Siswa Kelas X SMA Negeri 2 Sigi
}

\author{
Dita Puspitasari,Marungkil Pasaribu, dan Yusuf Kendek \\ e-mail: ditaphysic@gmail.com \\ Program Studi Pendidikan Fisika FKIP Universitas Tadulako \\ Jl. Soekarno Hatta Km. 9 Kampus Bumi Tadulako Tondo Palu - Sulawesi Tengah
}

Penelitian ini dilakukan dengan tujuan menguji signifikansi perbedaan hasil belajar fisika antara kelompok siswa yang diberi pembelajaran dengan model pembelajaran inkuiri terbimbing berbasis Peer Instruction dengan kelompok siswa yang diajar dengan model pembelajaran inkuiri terbimbing kelas X SMA Negeri 2 Sigi. Jenis penelitian yang digunakan adalah eksperimen kuasi dengan desain "Non ekivalen pretest-posttest design". Sampel dipilih dengan menggunakan teknik purposive sampling. Instrumen yang digunakan berupa tes hasil belajar dalam bentuk pilihan ganda. Berdasarkan tes hasil belajar fisika pada materi elastisitas yang diperoleh, menunjukkan bahwa nilai rata-rata untuk kelas eksperimen yaitu 19,37 dan standar deviasi sebesar 3,38, dan nilai rata-rata hasil belajar siswa untuk kelas kontrol yaitu 15,52 dan standar deviasi sebesar 3,13. Hasil uji t dua pihak dengan $\mathrm{dk}=47$ dan taraf signifikansi $\alpha=0,05$ diperoleh nilai $t_{\text {hitung }} 4,07$ dan nilai ini lebih besar dari $t_{\text {tabel }}(2,02)$. Nilai $t_{\text {hitung }}$ berada di luar daerah penerimaan $H_{0}$, dengan demikian $H_{0}$ ditolak dan $H_{1}$ diterima, sehingga dapat disimpulkan bahwa terdapat perbedaan yang signifikan pada hasil belajar fisika antara siswa yang diberi pembelajaran dengan model pembelajaran inkuiri terbimbing berbasis Peer Instruction dengan siswa yang diajar dengan model pembelajaran inkuiri terbimbing. Berdasarkan uji N-Gain diperoleh perbedaan yang signifikan pada hasil belajarnya untuk kelas eksperimen sebesar 56,87\% sedangkan pada kelas kontrol sebesar 33,19 \% kedua kelas tersebut berada pada kriteria sedang.

Kata Kunci: Inkuiri Terbimbing, Inkuiri Terbimbing Berbasis Peer Instruction, Hasil Belajar.

\section{PENDAHULUAN}

Pembelajaran merupakan suatu proses yang kompleks dan melibatkan berbagai aspek yang saling berkaitan. Dalam kegiatan pembelajaran terjadi proses interaksi (hubungan timbal balik) antara guru dengan siswa. Guru memberikan materi sementara siswa tidak hanya sekedar menerima begitu saja melainkan ada interaksi diantara keduanya sebagai suatu proses dalam rangka mencapai tujuan pembelajaran.

Pembelajaran fisika bukan hanya sekedar mengingat namun diperlukan pemahaman pada setiap materi yang diajarkan. Setiap materi dalam pelajaran fisika memiliki kumpulan teori, hukum, konsep, rumus, dan praktek dalam kehidupan sehari-hari. Akibatnya kebanyakan siswa mengatakan mata pelajaran fisika merupakan mata pelajaran yang cukup sulit.

Perlu adanya penjelasan tentang bagaimana sesungguhnya pemahaman peserta didik terhadap materi pelajaran fisika khususnya dalam pemahaman konsep siswa pada materi fisika. Proses belajar mengajar juga harus adanya keterlibatan siswa yang berperan aktif dalam proses pembelajaran agar siswa lebih mudah dan cepat memahami materi yang diajarkan. Kurangnya keterlibatan siswa dalam proses pembelajaran yang dikarenakan guru lebih mendominasi pembelajaran secara konvensional sehingga siswa cenderung bersifat pasif karena siswa hanya mendengarkan, mencatat, mengerjakan tugas yang diberikan oleh guru. Proses pembelajaran yang berpusat pada guru inilah yang dapat membuat siswa kurang mengerti dan tidak memahami materi yang diajarkan. Akibatnya siswa kurang memahami konsep-konsep yang ada pada materi pembelajaran.

Salah satu model pembelajaran yang dapat membantu peserta didik aktif dalam proses pembelajaran serta memperoleh pengetahuan dengan cara menemukan sendiri dan mengembangkan penguasaan konsep siswa adalah model pembelajaran inkuiri terbimbing berbasis Peer Instruction. Model pembelajaran inkuiri secara umum adalah pembelajaran yang dapat mengembangkan cara berpikir ilmiah yang menempatkan siswa sebagai pembelajar dalam memecahkan permasalahan dan memperoleh 
pengetahuan yang bersifat penyelidikan sehingga dapat memahami konsep-konsep sains. [1]

Pembelajaran inkuiri terbimbing para siswa bebas mengembangkan konsep yang mereka pelajari dengan bimbingan guru selama proses pembelajaran. Siswa diberi kesempatan untuk memecahkan masalah yang mereka hadapi secara individu atau berkelompok, di dalam kelas. Mereka juga diajarkan berinteraksi sosial dengan kawan sebayanya untuk saling bertukar informasi antar kelompok.

Peer Instruction (PI) dalam model pembelajaran inkuiri merupakan metode pembelajaran yang dapat mengembangkan partisipasi aktif siswa dalam kelompok serta meningkatkan penguasaan siswa terhadap konsep pada materi pembelajaran fisika. [2] Peer instruction diselingi dengan pertanyaan konsep dan melibatkan keaktifan siswa dalam pembelajaran. [3] Dengan kata lain Peer Instruction (PI) merupakan metode yang dapat mengaktifkan siswa dalam proses pembelajaran serta memudahkan siswa dalam mengusai konsep fisika melalui berpikir dan berdiskusi dengan teman sejawatnya.

Model pembelajaran inkuiri terbimbing berbasis Peer Instruction ini cocok digunakan pada materi yang terdapat konsep-konsep pembelajaran fisika serta menyajikan permasalahan yang dapat dipecahkan oleh siswa. Materi yang akan diteliti oleh peneliti yaitu materi elastisitas.

Peneliti bermaksud untuk melakukan penelitian tentang pengaruh model pembelajaran inkuiri terbimbing berbasis Peer Instruction terhadap hasil belajar fisika siswa kelas X SMA Negeri 2 Sigi.

\section{METODE PENELITIAN}

Penelitian yang digunakan adalah jenis penelitian dengan rancangan eksperimen kuasi (quasi-experimental design)

Desain penelitian yang digunakan yaitu the non equivalent pretest-posttest design. Desain penelitian yang digunakan dapat dilukiskan seperti pada Tabel 1. [4]

Tabel 1 Rancangan Prates-Pascates yang tidak Equivalent

\begin{tabular}{|l|c|c|c|}
\hline \multicolumn{1}{|c|}{ Kelompok } & Prates & Perlakuan & Pascates \\
\hline Eksperimen & $\mathrm{O}_{1}$ & $\mathrm{X}_{1}$ & $\mathrm{O}_{2}$ \\
\hline Kontrol & $\mathrm{O}_{1}$ & $\mathrm{X}_{2}$ & $\mathrm{O}_{2}$ \\
\hline
\end{tabular}

Keterangan:

$\mathrm{X}_{1}$ : Model pembelajaran inkuiri terbimbing berbasis peer instruction
$\mathrm{X}_{2}$ : Model pembelajaran inkuiri terbimbing

$\mathrm{O}_{1}$ : Tes awal

$\mathrm{O}_{2}$ : Tes akhir

$\mathrm{O}_{1}=\mathrm{O}_{2}$

Penelitian dilakukan di SMA Negeri 2 Sigi. Populasi dalam penelitian ini adalah seluruh siswa kelas X SMA Negeri 2 Sigi tahun pelajaran 2015/2016 yang terdiri dari 4 kelas. Sampel dalam penelitian ini adalah kelas $X$ MIA 1 yang berjumlah 25 siswa dan X MIA 4 yang berjumlah 24 siswa. Teknik pengumpulan sampel yang digunakan adalah purposive sampling, yaitu teknik penentuan sampel dengan pertimbangan tertentu.

Instrumen yang digunakan dalam penelitian ini adalah tes pilihan ganda untuk melihat hasil belajar siswa pada mata pelajaran fisika tentang elastisitas yang telah divalidasi oleh validator ahli. Analisis data dilakukan dengan menganalisis instrumen terlebih dahulu menggunakan uji validitas item dan reliabilitas tes yang kemudian dengan menganalisis data hasil penelitian menggunakan uji normalitas, uji homogenitas, uji hipotesis dan uji N-Gain.

\section{HASIL DAN PEMBAHASAN}

\section{- Hasil Penelitian}

Instrumen soal yang dibuat oleh peneliti berjumlah 60 soal dan selanjutnya di validasi oleh validasi ahli, berdasarkan hasil validasi ahli disetujui 49 soal, selanjutnya soal tersebut diuji cobakan pada siswa kelas XI SMA Negeri 2 Sigi.

Hasil analisis uji validitas item diperoleh rentang rpbi antara $-0,10-0,79$ dari hasil ini soal yang masuk dalam kategori sangat rendah berjumlah 13 soal, kategori rendah berjumlah 10 soal, kategori sedang berjumlah 20 soal dan kategori tinggi berjumlah 6 soal.

Besar nilai reliabilitas tes pada penelitian ini dibandingkan dengan nilai realibilitas tes yang ditentukan dalam tabel adalah $\left(r_{\text {hitung }}(0,89)>r_{\text {tabel }}(0,70)\right)$. Dari hasil tersebut dapat dikatakan bahwa nilai reliabilitas tes hasil perhitungan lebih besar dibandingkan nilai realibilitas tes yang ditentukan. Berdasarkan hasil tersebut dapat dinyatakan bahwa tes hasil belajar fisika siswa pada materi elastisitas yang disusun dapat memberikan hasil yang tetap, atau mempunyai taraf kepercayaan yang tinggi. Dengan kata lain, sejauh mana suatu tes dapat dipercaya untuk menghasilkan skor yang tetap, relatif tidak berubah walaupun diteskan pada situasi yang berbeda-beda. 
Berdasarkan hasil analisa data yang diperoleh, dari 49 item tes yang diuji cobakan pada siswa kelas XI MIA 1, tes yang memenuhi syarat untuk digunakan sebagai tes hasil belajar siswa adalah sebanyak 25 item, yang kemudian tes tersebut akan dites pada siswa kelas X MIA 4 (eksperimen) dan kelas X MIA 1 (kontrol).

Berdasarkan hasil pemberian Pretest diketahui skor minimum yang diperoleh siswa kelas $X$ MIA 4 (kelas eksperimen) yang berjumlah 24 siswa adalah 7 dan skor maksimum adalah 17 . Skor rata-rata kelas eksperimen sebesar 11,87 dan standar deviasi sebesar 3,13.

Sedangkan pada kelas X MIA 1 (kelas kontrol) yang berjumlah 25 siswa dengan skor minimum yang diperoleh siswa adalah 6 dan skor maksimumnya adalah 16 . Skor rataratanya sebesar 10,92 dan standar deviasi sebesar 3,12. Adapun data hasil penelitian di atas, disajikan pada tabel 2 .

Tabel 2. Deskripsi Skor Tes Hasil Belajar Fisika Kelas $X$ MIA 4 dan Kelas X MIA 1 (Pretest)

\begin{tabular}{|l|c|c|}
\hline \multicolumn{1}{|c|}{ Deskripsi } & $\begin{array}{c}\text { Kelas X MIA 4 } \\
\text { (Eksperimen) }\end{array}$ & $\begin{array}{c}\text { Kelas X MIA 1 } \\
\text { (Kontrol) }\end{array}$ \\
\hline Jumlah Siswa & 24 & 25 \\
\hline Skor Minimum & 7 & 6 \\
\hline Skor Maksimum & 17 & 16 \\
\hline Skor Ideal & 25 & 25 \\
\hline Skor Total & 285 & 273 \\
\hline Skor Rata-rata & 11,87 & 10,92 \\
\hline Standar Deviasi & 3,13 & 3,12 \\
\hline
\end{tabular}

Hasil perhitungan analisis uji normalitas Pretest dapat dilihat pada Tabel 3.

Tabel 3. Hasil Uji Normalitas Pretest Kelas Eksperimen dan Kelas Kontrol.

\begin{tabular}{|c|c|c|c|}
\hline Kelas & Nilai $\mathrm{X}^{2}$ Hitung & $\begin{array}{c}\text { Nilai } \\
\mathrm{X}^{2} \text { tabel }(\alpha=0,05)\end{array}$ & Keputusan \\
\hline $\begin{array}{c}\text { Kelas } \\
\text { Eksperimen }\end{array}$ & 3,16 & \multirow{2}{*}{7,81} & $\begin{array}{c}\text { Terdistribusi } \\
\text { normal }\end{array}$ \\
\cline { 1 - 2 } $\begin{array}{c}\text { Kelas } \\
\text { kontrol }\end{array}$ & 4,07 & $\begin{array}{c}\text { Terdistribusi } \\
\text { normal }\end{array}$ \\
\hline
\end{tabular}

Berdasarkan hasil uji normalitas pada tabel 3 dengan derajat kebebasan $\mathrm{dk}=\mathrm{k}-3=$ $6-3=3$ dengan peluang $(1-\alpha)=1-0,05$ $=0,95$ pada taraf signifikansi $\alpha=0,05$, maka nilai Chi-kuadrat tabel $\left(X^{2}\right.$ tabel) diperoleh sebesar $X^{2} 0,95(3)=7,81$ dan nilai ini lebih besar dari $X^{2}$ hitung kelas eksperimen 3,16 dan kelas kontrol 4,07 . Sesuai kriteria pengambilan keputusan, maka baik data dari kelas eksperimen maupun kelas kontrol keduanya berasal dari populasi yang terdistribusi normal.
Hasil perhitungan analisis uji homogenitas Pretest dapat dilihat pada Tabel 4.

Tabel 4. Hasil Uji Homogenitas Kelas Eksperimen dan Kelas Kontrol.

\begin{tabular}{|c|c|c|c|c|}
\hline Kelas & $\begin{array}{c}\text { Nilai } \\
\text { varians }\end{array}$ & $\begin{array}{c}\text { Nilai } \\
\text { Fhitung }\end{array}$ & $\begin{array}{c}\text { Nilai } \\
F_{\text {tabel }} \\
\mathrm{F} \alpha(\mathrm{v} 1, \mathrm{v} 2)\end{array}$ & Keputusan \\
\hline $\begin{array}{c}\text { Kelas } \\
\text { eksperimen }\end{array}$ & 471,347 & 1,12 & 1,97 & $\begin{array}{c}\text { Kedua } \\
\text { data } \\
\text { homogen }\end{array}$ \\
$\begin{array}{c}\text { Kelas } \\
\text { kontrol }\end{array}$ & 529,573 & & & \\
\hline
\end{tabular}

Berdasarkan hasil uji homogenitas pada tabel 4, dengan derajat kebebasan untuk pembilang $\left(n_{1}\right)=24$ dan penyebut $\left(n_{2}\right)=25$ pada taraf signifikansi $\alpha=0,05$, maka nilai Ftabel diperoleh sebesar $F_{0,05(24,25)}=1,97$ dan nilai ini lebih besar dari nilai Fhitung $(1,12)$. Berdasarkan kriteria pengambilan keputusan, diketahui data tersebut memiliki varians yang sama atau homogen. Artinya tidak terdapat perbedaan varians antara kelas eksperimen maupun kelas kontrol.

Hasil perhitungan analisis uji beda dua rata-rata (dua pihak) Pretes dapat dilihat pada Tabel 5.

Tabel 5. Uji Beda Rata-rata (Dua Pihak) Pretest Kelas Eksperimen dan Kelas Kontrol

\begin{tabular}{|c|c|c|c|c|}
\hline Kelas & $\begin{array}{c}\text { Nilai } \\
\text { rata-rata }\end{array}$ & $t_{\text {hitung }}$ & $t_{\text {tabel }}$ & Keputusan \\
\hline $\begin{array}{c}\text { Kelas } \\
\text { Eksperimen }\end{array}$ & 12,00 & \multirow{2}{*}{1,11} & 2,02 & $\begin{array}{c}\mathrm{H}_{\circ} \\
\text { diterima }\end{array}$ \\
\hline $\begin{array}{c}\text { Kelas } \\
\text { Kontrol }\end{array}$ & 10,98 & & \\
\hline
\end{tabular}

Berdasarkan hasil uji beda dua rata-rata pada tabel 5, dengan derajat kebebasan $\mathrm{dk}=\left(\mathrm{n}_{1}+\mathrm{n}_{2}-2\right)=24+25-2=47$ dengan peluang $\left(1-\frac{1}{2} a\right)=1-(0,5 \times 0,05)=0,975$ dan taraf signifikansi $\alpha=0,05$, maka nilai tabel diperoleh sebesar $t_{0,975(47)}=2,02$ dan nilai ini lebih besar dari nilai thitung $(1,11)$. Hal ini menunjukkan bahwa nilai thitung berada diantara daerah penerimaan $\mathrm{H}_{0}$. Dapat disimpulkan bahwa tidak terdapat perbedaan hasil belajar fisika antara kelompok siswa yang mengikuti model pembelajaran inkuiri terbimbing berbasis Peer Instruction di kelas X MIA 4 dengan model pembelajaran inkuiri terbimbing di kelas X MIA 1.

Hasil pemberian posttest diketahui skor minimum yang diperoleh siswa kelas X MIA 4 (kelas eksperimen) yang berjumlah 24 siswa adalah 14 dan skor maksimum adalah 24. Skor rata-rata kelas eksperimen sebesar 19,37 dan 
standar deviasi sebesar 3,38. Sedangkan pada kelas X MIA 1 (kelas kontrol) yang berjumlah 25 siswa dengan skor minimum yang diperoleh siswa adalah 10 dan skor maksimumnya adalah 20. Skor rata-ratanya sebesar 15,52 dan standar deviasi sebesar 3,13. Adapun data hasil penelitian di atas, disajikan pada tabel 6 .

Tabel 6. Deskripsi Skor Tes Hasil Belajar Fisika Kelas X MIA 4 dan Kelas X MIA 1 (Posttest)

\begin{tabular}{|l|c|c|}
\hline \multicolumn{1}{|c|}{ Deskripsi } & $\begin{array}{c}\text { Kelas X MIA 4 } \\
\text { (Eksperimen) }\end{array}$ & $\begin{array}{c}\text { Kelas X MIA 1 } \\
\text { (Kontrol) }\end{array}$ \\
\hline Jumlah Siswa & 24 & 25 \\
\hline Skor Minimum & 14 & 10 \\
\hline Skor Maksimum & 24 & 20 \\
\hline Skor Ideal & 25 & 25 \\
\hline Skor Total & 465 & 388 \\
\hline Skor Rata-rata & 19,37 & 15,52 \\
\hline Standar Deviasi & 3,38 & 3,13 \\
\hline
\end{tabular}

Hasil perhitungan analisis uji hipotesis Posttest dapat dilihat pada Tabel 7.

Tabel 7. Uji Hipotesis Posttest Kelas Eksperimen dan Kelas Kontrol

\begin{tabular}{|c|c|c|c|c|}
\hline Kelas & $\begin{array}{c}\text { Nilai } \\
\text { rata-rata } \\
\bar{X}\end{array}$ & $\mathrm{t}_{\text {hitung }}$ & $\mathrm{t}_{\text {tabel }}$ & Keputusan \\
\hline $\begin{array}{c}\text { Kelas } \\
\text { Eksperimen }\end{array}$ & 19,33 & \multirow{2}{*}{4,07} & 2,02 & $\mathrm{H}_{\mathrm{o}}$ ditolak \\
$\begin{array}{c}\text { Kelas } \\
\text { Kontrol }\end{array}$ & 15,46 & & \\
\hline
\end{tabular}

Berdasarkan data tabel 7 diketahui nilai thitung $(4,07)>$ tabel $(2,02)$. Hal ini menunjukkan bahwa nilai thitung berada di luar daerah penerimaan $\mathrm{H}_{0}$. Dengan demikian $\mathrm{H}_{0}$ ditolak dan $\mathrm{H}_{1}$ diterima, dan dapat disimpulkan bahwa terdapat perbedaan hasil belajar fisika antara kelompok siswa yang mengikuti model pembelajaran inkuiri terbimbing berbasis Peer Instruction di kelas $X$ MIA 4 dengan model pembelajaran inkuiri terbimbing di kelas X MIA 1.

Hasil perhitungan analisis uji $\mathrm{N}$-gain Posttest dapat dilihat pada Tabel 8.

Tabel 8. Hasil Uji N-Gain Kelas Eksperimen dan Kelas Kontrol

\begin{tabular}{|c|c|c|c|c|}
\hline \multirow{2}{*}{ Uraian } & \multicolumn{2}{|c|}{ Kelas Eksperimen } & \multicolumn{2}{c|}{ Kelas Kontrol } \\
\cline { 2 - 5 } & Pretes & Posttes & Pretest & Posttest \\
\hline Nilai rendah & 7 & 14 & 6 & 10 \\
\hline Nilai tinggi & 17 & 24 & 16 & 20 \\
\hline Nilai rata-rata & 11,88 & 19,38 & 10,92 & 15,52 \\
\hline Sampel & \multicolumn{2}{|c|}{24} & \multicolumn{2}{c|}{25} \\
\hline N-Gain & \multicolumn{2}{|c|}{56,87} & \multicolumn{2}{c|}{33,19} \\
\hline Kriteria & \multicolumn{2}{|c|}{ Sedang } & \multicolumn{2}{c|}{ Sedang } \\
\hline
\end{tabular}

Berdasarkan data tabel 8 dapat dilihat bahwa kualitatif skor $\mathrm{N}$-gain kelas eksperimen maupun kelas kontrol berada dikriteria sedang. Namun berdasarkan data kuantitatif skor $\mathrm{N}$-gain pada kelas eksperimen berbeda secara signifikan dengan kelas kontrol. Hal ini menunjukkan bahwa, pada kelas ekperimen berbeda secara signifikan dengan kelas kontrol, sehingga dapat disimpulkan bahwa ada pengaruh penggunaan model pembelajaran inkuiri terbimbing berbasis Peer Instruction terhadap hasil belajar fisika kelas X SMA Negeri 2 Sigi.

\section{- Pembahasan}

Berdasarkan analisa data hasil penelitian yang dilakukan, maka pada bagian ini akan dibahas tentang pengaruh model pembelajaran inkuiri terbimbing berbasis Peer Instruction terhadap hasil belajar fisika kelas $X$ SMA Negeri 2 Sigi. Hal ini dilakukan dengan cara memberikan dua perlakuan yang berbeda, yaitu pada kelas eksperimen dengan menggunakan model pembelajaran inkuiri terbimbing berbasis Peer Instruction dan kelas kontrol dengan menggunakan model pembelajaran inkuiri terbimbing melalui hasil belajar yang diperoleh dari pretest dan posttest.

Berdasarkan hasil pengolahan data yang telah dilakukan, diketahui bahwa kemampuan awal siswa masih rendah, hal ini dapat dilihat dari pemberian tes awal (pretest) dengan skor rata-rata sebesar 11,87 dengan standar deviasi 3,13 sedangkan skor rata-rata pada kelas kontrol sebesar 10,92 dengan standar deviasi 3,12 . Pemberian pretest pada kedua kelas tersebut, dapat diketahui bahwa ternyata belum terdapat perbedaan hasil belajar yang signifikan antara kedua kelas karena belum diberikan penerapan model pembelajaran yang akan diteliti serta belum mendapatkan pembelajaran tentang materi elastisitas sebelumnya. Dari data hasil analisis terlihat bahwa hasil belajar kedua kelas tersebut masih rendah.

Setelah diberi perlakuan model pembelajaran inkuiri terbimbing berbasis Peer Instruction pada kelas eksperimen dan model pembelajaran inkuiri terbimbing pada kelas kontrol, kedua kelas tersebut memperoleh peningkatan hasil belajar dari keadaan awal. Hal tersebut dapat dilihat melalui hasil pemberian tes akhir yang diberikan pada kelas eksperimen dan kelas kontrol. Pencapaian skor rata-rata pada kelas eksperimen sebesar 19,37 dengan standar deviasi 3,38, sedangkan skor 
rata-rata pada kelas kontrol sebesar 15,52 dengan standar deviasi 3,13.

Uji hipotesis dua pihak diperoleh thitung $>$ tabel atau 4,07 > 2,02. Hal ini menunjukkan bahwa nilai thitung berada di luar daerah penerimaan $\mathrm{H}_{0}$. Dengan demikian $\mathrm{H}_{0}$ ditolak dan $\mathrm{H}_{1}$ diterima, dan dapat disimpulkan bahwa terdapat perbedaan yang signifikan pada hasil belajar fisika antara kelompok siswa yang mengikuti model pembelajaran inkuiri terbimbing berbasis Peer Instruction di kelas $X$ MIA 4 dengan model pembelajaran inkuiri terbimbing di kelas X MIA 1.

Setelah dilakukan uji hipotesis kemudian dilakukan uji N-gain yaitu uji peningkatan hasil belajar yang diperoleh dari kelas eksperimen dan kelas kontrol. Skor $\mathrm{N}$-gain pada kelas eksperimen yang diperoleh sebesar 56,87\% sedangkan pada kelas kontrol sebesar 33,19\%. Berdasarkan patokan kriteria tingkat Gain dimana $30 \leq \mathrm{g}<70$ dinyatakan dalam kategori sedang. Secara kualitatif kelas eksperimen dinyatakan berada pada kategori sedang begitupun untuk kelas kontrol. Tetapi jika ditinjau secara kuantitatif untuk kelas ekperimen berbeda secara signifikan pada hasil belajarnya dengan kelas kontrol. Berdasarkan hasil analisis data perhitungan dapat disimpulkan bahwa pada kelas eksperimen menunjukkan adanya pengaruh model pembelajaran yang digunakan.

Berdasarkan hasil penelitian tersebut dapat dilihat bahwa dengan memberikan perlakuan yang berbeda pada kelas ekperimen dan kelas kontrol, akan memperoleh hasil belajar yang berbeda. Perbedaan hasil belajar tersebut dapat dilihat dari skor pretes maupun skor posttest pada kelas ekperimen dan kelas kontrol yang menunjukkan adanya pengaruh model pembelajaran yang digunakan pada kedua kelas tersebut. Pengaruh hasil belajar yang lebih baik terjadi pada kelas eksperimen, karena pada kelas ekperimen menggunakan model pembelajaran inkuiri terbimbing berbasis Peer Instruction. Siswa pada kelas eksperimen dituntut aktif dalam proses pembelajaran serta memudahkan siswa dalam mengusai konsep fisika melalui berpikir dan berdiskusi dengan teman sejawatnya. Sedangkan pada kelas kontrol siswa juga dituntut untuk memecahkan masalah yang mereka hadapi secara berkelompok, di dalam kelas dengan adanya bimbingan dari guru.

Tahap-tahap pembelajaran yang dilakukan pada kelas eksperimen dengan menggunakan inkuiri terbimbing berbasis Peer
Instruction yaitu terdiri dari enam fase pembelajaran. Pada tahap pertama yaitu orientasi masalah secara Peer, dimana guru melakukan demonstrasi yang dibantu dengan salah satu siswa. Setelah itu, siswa merumuskan masalah berdasarkan pada demonstrasi dan sebelum masuk kegiatan inti siswa diberikan tes konsep oleh guru. Hal ini bertujuan agar siswa akan lebih maksimal dalam keterlibatannya pada pembelajaran. Tes konsep dapat mengungkapkan kesulitan siswa terhadap materi yang akan diajarkan.

Pada tahap kedua, yaitu tahap berhipotesis secara Peer. Pada tahap ini, siswa mengerjakan tes konsep secara individu dan berdiskusi secara Peer tentang hipotesis yang akan diajukan. Pemberian tes konsep di awal pembelajaran dapat membuat siswa lebih terfokus pada materi yang akan diajarkan serta mempersiapkan siswa dalam memasuki pembelajaran inti.

Tahap ketiga yaitu menguji hipotesis secara peer. Pada tahap ini, guru membimbing siswa untuk membentuk kelompok yang beranggotakan 2 orang, yaitu dengan teman sebangkunya (secara Peer). Guru membagikan LKS mengenai materi yang akan dipelajari yaitu materi elastisitas serta alat dan bahan yang akan digunakan untuk melakukan eksperimen kepada setiap kelompok. Guru membimbing siswa untuk melakukan percobaan guna menguji hipotesis yang dibuat oleh siswa, serta menjelaskan kepada siswa untuk mengikuti prosedur yang ada di LKS serta cara pengisian analisa data dan pertanyaan yang tercantum pada LKS tersebut guna memudahkan siswa dalam proses menganalisa data. Dalam menganalisa data siswa dapat mengembangkan penguasaan konsep melalui keaktifan siswa dalam berdiskusi secara Peer. Kemudian siswa juga diberikan waktu untuk berdiskusi tes konsep yang diberikan di awal pembelajaran dengan teman sejawatnya.

Tahap ke empat yaitu tahap presentasi data secara peer. Pada tahap ini, siswa berdiskusi tentang hasil eksperimen yang telah dilakukan dengan teman sejawatnya untuk menguji hipotesi yang telah dibuat yang kemudian akan dipresentasikan didepan kelas dan ditanggapi kelompok lain. Pada tahap ini juga, guru memberikan kesempatan kepada siswa untuk menyampaikan jawaban dari pertanyaan tes konsep yang diberikan diawal pembelajaran.

Tahap ke lima yaitu tahap umpan balik. Pada tahap ini, guru memberikan penguatan 
tentang hasil eksperimen serta memberikan konfirmasi dari tes konsep yang diberikan di awal pembelajaran.

Tahap ke enam yaitu tahap penarikan simpulan secara peer. Pada tahap ini bersama dengan teman sejawatnya siswa memikirkan tentang kesimpulan apa yang dapat diambil dari hasil ekperimen yang telah dilakukan, dan ditanggapi oleh kelompok lainnya. Kemampuan untuk memahami konsep dari pelajaran yang telah dipelajari melalui eksperimen secara Peer dapat membuat siswa terasah dan siswa mampu menguasai konsep yang dipelajari.

Tahap-tahap pembelajaran pada kelas kontrol hampir memiliki persamaan dengan tahap-tahapan pada kelas eksperimen, yaitu dimulai dengan menyajikan masalah, membuat hipotesis, melakukan eksperimen untuk memperoleh data, mengumpulkan dan menganalisis data serta membuat kesimpulan. Namun perbedannya adalah dimana pada kelas kontrol, diskusi dilakukan dengan lima orang dalam satu kelompok tidak secara Peer. Hal ini bertujuan untuk mengetahui keaktifan siswa dalam mengikuti proses pembelajaran dan untuk mengetahui siswa yang mudah memahami konsep yang ada pada materi yang disampaikan, kemudian nantinya akan diketahui perbedaan hasil belajar dari kedua kelas tersebut.

Pada kelas kontrol dengan menggunakan model pembelajaran inkuiri terbimbing masih terdapat siswa yang kurang aktif dalam proses pembelajaran, terutama pada saat berdiskusi dengan pembagian lima orang dalam satu kelompok menyebabkan kondisi kelas menjadi lebih ramai, dan hanya dua atau tiga orang saja dalam satu kelompok tersebut yang aktif dalam kegiatan diskusi baik dari pengambilan data, menganalisis data, serta membuat kesimpulan. Sedangkan teman kelompok yang lain lebih cenderung pasif dan tidak terlibat langsung dalam proses diskusi atau terkadang teman yang tidak mengikuti diskusi lebih memilih untuk bermain dan tidak membantu teman satu kelompoknya. Hal ini menyebabkan proses belajar dan konsentrasi siswa kurang maksimal, sehingga pada saat ditanya kembali mengenai materi yang telah diajarkan masih ada siswa yang masih bingung karena tidak terlibat aktif dalam proses pembelajaran.

Sedangkan pada kelas eksperimen dengan menggunakan model pembelajaran inkuiri terbimbing berbasis Peer Instruction, siswa lebih aktif dalam proses pembelajarannya, serta siswa lebih mudah dalam menemukan dan dapat mengembangkan konsep saat melakukan praktikum yaitu pada tahap menguji hipotesis secara Peer dan berdiskusi secara Peer di setiap tahap pembelajaran sehingga siswa dapat lebih mudah menguasai konsep dalam pokok bahasan yang dipelajari. Selain itu diskusi secara Peer juga dapat membuat siswa lebih mudah mengingat materi yang diajarkan. Kelompok - kelompok yang dibentuk sesuai dengan posisi duduk siswa yaitu teman sebangku, dapat memiliki efek positif dalam proses pembelajaran. Hal ini sesuai dengan penelitian sebelumnya [5] yang menyatakan teman-teman yang duduk di dekatnya umumnya lebih membiasakan dengan kebutuhan dan tujuan masing-masing dan membuat mereka membangun pemahaman bersama. Teman dekat umumnya lebih bersedia untuk menjelaskan ide mereka sebagai hasil dari kepercayaan satu sama lain, dan rasa hormat antar teman sehingga mereka dapat menghargai ide satu sama lain. Kepercayaan satu sama lain dengan teman sebangkunya dapat membuat mereka lebih bisa mengungkapkan ide serta gagasan mereka. Hal ini membuat mereka lebih bisa mengembangkan konsep yang mereka pelajari dan lebih mudah mengerti dengan materi yang diajarkan.

Penelitian ini sejalan dengan penelitian sebelumnya [6] dengan judul pengaruh model pembelajaran inkuiri terbimbing terhadap hasil belajar fisika siswa kelas VIII SMP Negeri 4 Metro semester genap tahun pelajaran 2013/2014, menyatakan model pembelajaran inkuiri terbimbing berpengaruh signifikan terhadap hasil belajar fisika siswa kelas VIII SMP Negeri 4 Metro. Ada beberapa faktor yang menyebabkan model pembelajaran inkuiri terbimbing berpengaruh terhadap hasil belajar fisika siswa diantaranya yaitu: terlaksananya langkah-langkah kegiatan dengan model inkuiri terbimbing dalam proses pembelajaran, permasalahan yang disajikan dalam LKS mampu membangkitkan minat dan rasa ingin tahu siswa, alat-alat praktikum yang menunjang kegiatan pembelajaran dan adanya kesempatan siswa untuk mengkomunikasikan hasil diskusi.

Sesuai dengan penelitian terdahulu [7] dengan judul pengaruh pembelajaran inkuiri terbimbing integrasi Peer Instruction terhadap penguasaan konsep dan kemampuan berpikir kritis siswa yang menyatakan terdapat perbedaan penguasaan konsep dan 
kemampuan berpikir kritis fisika siswa yang menggunakan pembelajaran inkuiri terbimbing integrasi Peer Instruction, pembelajaran inkuiri terbimbing dan pembelajaran konvensional. Selanjutnya, penguasaan konsep siswa yang belajar dengan pembelajaran inkuiri terbimbing integrasi Peer Instruction lebih tinggi daripada siswa yang belajar dengan pembelajaran inkuiri terbimbing dan pembelajaran konvensional. Terakhir, kemampuan berpikir kritis siswa yang belajar dengan pembelajaran inkuiri terbimbing integrasi Peer Instruction lebih tinggi daripada siswa yang belajar dengan pembelajaran inkuiri terbimbing dan pembelajaran konvensional. Hasil penelitian ini disebabkan karena pada pembelajaran inkuiri terbimbing integrasi peer instruction, siswa diasah kemampuan berpikir kritisnya dan dikembangkan penguasaan konsepnya melalui eksperimen dan diskusi secara peer. Penambahan diskusi secara Peer (teman sejawat) pada setiap tahap, juga dapat mengaktifkan keterlibatan siswa dalam pembelajaran. Siswa yang pasif, akan cenderung termotivasi untuk mengemukakan pendapatnya karena memiliki kesempatan yang sama. Hasil penelitian ini juga diperkuat dengan penelitian sebelumnya [8] yang menyatakan bahwa siswa lebih mudah mengonstruksi pemahaman dan kemampuan pemecahan masalah jika mereka melakukan sharing dalam belajar.

Berdasarkan hasil analisis data tersebut dapat disimpulkan bahwa adanya perbedaan hasil belajar fisika antara kelompok siswa yang diberi pembelajaran dengan model pembelajaran inkuiri terbimbing berbasis Peer Instruction dengan kelompok siswa yang diajar dengan model pembelajaran inkuiri terbimbing kelas X SMA Negeri 2 Sigi. Hal ini dikarenakan model pembelajaran inkuiri terbimbing berbasis Peer Instruction dapat membuat siswa terlibat aktif dalam proses pembelajaran dengan adanya bimbingan dari guru, siswa mampu berpikir secara maksimal dalam menguasai konsep serta dapat membuktikan konsep secara nyata melalui ekperimen dan dapat mengembangkan konsep yang dipelajari dengan teman sejawatnya serta dapat meningkatkan hasil belajar fisika dan minat siswa untuk belajar fisika.

Selain dari kelebihan tersebut, adapula kekurangan dari model ini yaitu membutuhkan waktu yang cukup lama dalam bereksperimen baik dari proses pengambilan data, siswa yang masih bingung dalam menganalisa data serta membuat kesimpulan dari eksperimen yang dilakukan. Oleh karena itu guru harus memantau proses pembelajaran terutama pada saat masuk ke pembelajaran inti yaitu bereksperimen, guru tak boleh luput dalam mengingatkan serta menjelaskan terlabih dahulu langkah kerja dan cara menganalisa data agar siswa tidak kebingungan selama proses bereksperimen serta memudahkan siswa dalam pembuatan kesimpulan dari hasil ekperimen yang telah dilakukan.

\section{KESIMPULAN DAN SARAN}

Berdasarkan hasil penelitian dan analisa data hasil penelitian dapat dinyatakan bahwa terdapat perbedaan yang signifikan pada hasil belajar fisika antara kelompok siswa yang diberi pembelajaran dengan model pembelajaran inkuiri terbimbing berbasis Peer Instruction dengan kelompok siswa yang diajar dengan model pembelajaran inkuiri terbimbing kelas $X$ SMA Negeri 2 Sigi.

Berdasarkan kesimpulan ada beberapa saran yang dapat dikemukakan: (1) untuk peneliti selanjutnya, jika ingin menggunakan model pembelajaran inkuiri terbimbing berbasis Peer Instruction dapat dilakukan perbaikan pada perencanaan waktu pembelajaran, yaitu dengan mengurangi waktu praktikum. Agar pembelajaran berjalan sesuai perencanaan serta tidak melebihi waktu yang ditentukan. (2) untuk peneliti selanjutnya, jika ingin melakukan penelitian yang sama dengan menggunakan model pembelajaran inkuiri terbimbing berbasis Peer Instruction, disarankan dengan materi yang berbeda, karakteritik konseptual serta dapat dibandingkan dengan model pembelajaran yang berbeda sehingga dapat digunakan sebagai bahan pertimbangan dalam penerapannya disekolah.

\section{DAFTAR PUSTAKA}

[1] Amilasari, A. \& Sutiadi, A. (2008). Peningkatan Kecakapan Akademik Siswa SMA dalam Pembelajaran Fisika melalui Penerapan Inkuiri Terbimbing. Jurnal Pengajaran MIPA, FMIPA UPI [Online]. Vol 12 No 02 Tahun 2008. Tersedia: http://file.upi.edu/ Direktori /FPMIPA/Jur._Pend._Fisika/197009081997021-Asep_ Sutiadi/Peningkatan_Kecakapan_Akademik_Asep_ Suiadi.Pdf [11 November 2015].

[2] Crouch, C. H. \& Mazur, E. (2001). Peer Instruction: Ten years of experience and results. Department of Physics, Harvard University, Cambridge. American Journal of Physics [Online]. Vol 69 No 09 Tahun 2001. Tersedia:http://web.mit.edu/jbelcher/www/TEALref/ Crouch_Mazur.pdf [12 November 2015].

[3] Fagen, A. P., Crouch, C. H., dan Mazur, E. (2002). Peer Instruction: Results from a Range of Classrooms., 
Harvard University, Cambridge [Online]. Tersedia: http://www.physics.utoronto.ca/ key/PHY1600/PER\% 20Papers/Mazur\%20Peer\%20Instruction\%20results.p df[07 Agustus 2015].

[4] Sugiyono. (2009). Metode Penelitian Pendidikan (Pendekatan Kuantitatif, Kualitatif dan R\&D). Bandung : Alfabeta

[5] P. Heller, R. Keith, and S. Anderson. (1992). Teaching problem solving through cooperative grouping Part 1:Groups versus individual problem solving. American Journal of Physics [Online]. Vol 60 No 07 Tahun 1992. Tersedia:https://d1b10bmlvqabco.cloudfront.net/attac h/i5li1rs55o12sy/hsg4ulhusig4id/i6cjt6dficgt/Helleretal _92_AJP.pdf [01 November 2015].

[6] Partono. (2015). Pengaruh Model Pembelajaran Inkuiri Terbimbing Terhadap Hasil Belajar Fisika Siswa Kelas VIII SMP Negeri 4 Metro Semester Genap Tahun Pelajaran 2013/2014. Jurnal pendidikan Fisika [Online]. Vol 3 No 01 Tahun 2015.Tersedia:http://fkip.ummetro.ac.id/journal/index .php/fisika/article/view/27/19 [01 November 2015].

[7] Kurniawati, I.D. Dkk. (2014). Pengaruh Pembelajaran Inkuiri Terbimbing Integrasi Peer Instruction Terhadap Penguasaan Konsep Dan Kemampuan Berpikir Kritis Siswa. Jurnal pendidikan fisika Indonesia [Online]. Vol $10 \quad$ No $\quad 01 \quad$ Tahun 2014. Tersedia:http://journal.unnes.ac.id/nju/index.php/jpfi[ 30 Juli 2015].

[8] Slavin, R.E. (2005). Cooperative Learning: Teori, Riset, dan Praktik. (Terjamah oleh Nurulita). Bandung: Nusa Media. 